\title{
Pengaruh sumber pembiayaan desentralisasi fiskal terhadap Produk Domestik Regional Bruto dan tingkat kemiskinan (Studi di kabupaten-Kota di Provinsi Jambi)
}

\author{
Agung Ridwan; Syaparuddin; Candra Mustika*
}

\author{
Prodi Ekonomi Pembangunan, Fakultas Ekonomi dan Bisnis, Universitas Jambi \\ *E-mail korespondensi: bluemickeyid@yahoo.com
}

\begin{abstract}
This study aims to analyze: 1) sources of financing for fiscal decentralization, GRDP and poverty levels of regencies / cities in Jambi Province (2) the effect of sources of fiscal decentralization financing on gross domestic product in regencies and cities in Jambi Province (3) the effect of fiscal decentralization financing sources towards poverty levels in regencies and cities in Jambi Province. The analysis period is 2007 2013. To analyze the influence of the sources of fiscal decentralization funding on GRDP and poverty levels, using two panel data regression models. The results of the analysis found that: 1) During the 2007-2013 period, the sources of financing for fiscal decentralization consisting of Local Original Revenue, Balanced Funds and Other Other Income in regencies and cities in Jambi Province generally increased every year; 2) The GRDP regency-city growth in Jambi Province is fairly high with an average of $6.83 \%$, higher than the national economic growth; 3) In general, the poverty rate of regencies/cities in Jambi Province has decreased significantly every year during the period 2007 - 2013. Original Regional Revenue and other legitimate income have a negative and significant effect while the balance fund does not have a significant effect on the poverty level of regencies/cities in Jambi Province.
\end{abstract}

Keywords: Fiscal Decentralization, Poverty Level, Panel Data.

\begin{abstract}
Abstrak.
Penelitian ini bertujuan untuk menganalisis: 1) sumber pembiayaan desentralisasi fiskal, PDRB dan tingkat kemiskinan kabupaten-kota di Provinsi Jambi (2) pengaruh sumber pembiayaan desentralisasi fiskal terhadap produk domestik bruto di kabupaten-kota di Provinsi Jambi (3) pengaruh sumber pembiayaan desentralisasi fiskal terhadap tingkat kemiskinan di kabupaten-kota di Provinsi Jambi. Periode analisis adalah Tahun 2007 2013. Untuk menganlisis pengaruh sumber pembiayaan desentralisasi fiskal terhadap PDRB dan tingkat kemiskinan digunakan dua model regresi data panel. Hasil analisis menemukan bahwa: 1) Selama periode 2007-2013, sumber pembiayaan desentralisasi fiskal yang terdiri Pendapatan Asli Daerah, Dana Perimbangan dan Pendapatan Lainlain yang Sah di kabupaten-kota di Provinsi Jambi umumnya selalu mengalami kenaikan setiap tahunnya; 2) Pertumbuhan PDRB kabupaten-kota di Provinsi Jambi terbilang cukup tinggi dengan rata-rata 6,83\%, lebih tinggi dari pertumbuhan ekonomi nasional; 3) Secara umum, tingkat kemiskinan kabupaten-kota di Provinsi Jambi selalu mengalami penurunan yang signifikan setiap tahunnya selama periode 2007 - 2013; 4) $\mathrm{PAD}$, dana perimbangan dan dan pendapatan lain yang sah mempunyai pengaruh positif dan signifikan terhadap peningkatan produk domestik regional bruto kabupatenkota di Provinsi Jambi; 5) PAD dan pendapatan lain yang sah mempunyai pengaruh yang negatif dan signifikan sedangkan dana perimbangan tidak memiliki pengaruh yang signifikan terhadap tingkat kemiskinan kabupaten-kota di Provinsi Jambi.
\end{abstract}

Kata Kunci : Desentralisasi Fiskal, Tingkat Kemiskinan, Data Panel. 


\section{PENDAHULUAN}

Pembangunan nasional merupakan salah satu upaya untuk mewujudkan tujuan masyarakat yakni kesejahteraan yang adil dan makmur. Sejalan dengan tujuan tersebut, berbagai kegiatan pembangunan nasional diarahkan kepada pembangunan yang merata ke setiap daerah, khususnya daerah yang cenderung masih memiliki kelemahan dalam penerimaan pendapatannya. Kegiatan pembangunan nasional tidak lepas dari peran pemerintah daerah dalam memanfaatkan sumber daya yang tersedia di daerah masingmasing sebagai upaya memperbesar kemampuan daerah. Untuk itu peningkatannya harus didukung dengan pembangunan daerah yang dilaksanakan secara serasi dan terpadu dalam rangka mewujudkan pembangunan nasional. Pembangunan ekonomi daerah adalah suatu proses dimana pemerintah daerah dan masyarakatnya mengelola sumber-sumber daya yang ada dan membentuk suatu pola kemitraan antara pemerintah daerah dan sektor swasta untuk menciptakan suatu lapangan pekerjaan baru dan merangsang perkembangan kegiatan ekonomi dalam wilayah tersebut (Arsyad, 2010).

Proses pembangunan di daerah memerlukan Produk Domestik Regional Bruto (PDRB) yang tinggi agar pertumbuhan ekonomi lebih cepat tumbuh. Menurut Todaro (2004) yang menyatakan bahwa, perekonomian yang tinggi disuatu wilayah tidak mencerminkan kesejahteraan yang merata bagi seluruh masyarakat wilayah tersebut. Selain itu, tingkat pertumbuhan ekonomi yang cepat tidak dengan sendirinya diikuti oleh pertumbuhan atau perbaikan distribusi keuntungan bagi segenap penduduk. Peningkatan serta tingginya pertumbuhan ekonomi di Provinsi Jambi diharapkan terjadi secara merata dan dapat meningkatkan kesejahteraan masyarakat. Kemiskinan merupakan masalah dalam pembangunan yang bersifat multidimensi. Kemiskinan merupakan persoalan kompleks yang terkait dengan berbagai dimensi yakni sosial, ekonomi, budaya, politik serta dimensi ruang dan waktu (Arsyad, 2010).

Reformasi yang dimulai beberapa tahun lalu telah merambah keseluruh aspek kehidupan. Salah satu aspek reformasi yang dominan adalah aspek pemerintahan. Aspek pemerintahan yang dimaksud disini adalah aspek hubungan antara pemerintah pusat dan pemerintah daerah. pada aspek ini masalah yang ditimbulkan adalah tuntutan otonomi yang sangat besar yang harus diberikan kepada daerah. Otonomi daerah dan desentralisasi merupakan langkah yang strategis bagi bangsa Indonesia untuk menghadapi era globalisasi ekonomi dengan memperkuat basis perekonomian daerah yang diharapkan dapat mempercapat laju Pertumbuhan Produk Domestik Bruto serta mengurangi tingkat kemiskinan. Tuntutan ini kemudian melahirkan undang-undang otonomi daerah, yaitu UU no. 22 tahun 1999 tentang pemerintah daerah dan UU No. 25 tahun 1999 tentang perimbangan keuangan pemerintah pusat dan daerah dan sekaligus menjadi awal era baru desentralisasi fiskal di Indonesia. Sasaran utama desentralisasi adalah dapat membantu mempercepat perkembangan pertumbuhan ekonomi yang dilihat dari pertumbuhan PDRB atas dasar harga konstan 2000 di daerah serta desentralisasi fiskal merupakan sebuah solusi agar pemerintah dapat lebih efisien dalam menjalankan roda pemerintahannya dari tingkat yang lebih rendah (tricckle down effect). Menurut undang-undang No. 32 tahun 2004, sumber pembiayaan pelaksanaan desentralisasi terdiri dari: (1) Pendapatan Asli Daerah (PAD) (2) Dana Perimbangan, dan (3) Pendapatan lain-lain yang sah.

Kaitan desentralisasi fiskal dengan PDRB dan kemiskinan dapat dijelaskan dari beberapa teori bahwa desentralisasi fiskal membuat pemerintah lebih responsif terhadap aspirasi dan preferensi kebutuhan masyarakat dibanding dengan pemerintah yang terpusat agar tercipta sebuah kesejahteraan masyarakat. Desentralisasi fiskal mempunyai peran penting dalam mengurangi kemiskinan mulai dari pedesaan hingga ke perkotaan karena desentralisasi fiskal adalah suatu proses distribusi anggaran dari tingkat pemerintah yang lebih tinggi kepada pemerintah yang lebih rendah untuk 
mendukung fungsi atau tugas pemerintahan dan layanan publik sesuai dengan banyaknya kewenangan bidang pemerintahan yang dilimpahkan. Penelitian ini dianggap penting karena di Indonesia telah melaksanakan desentralisasi sejak tahun 1974 berdasarkan UU No 5 th 1974, yang kemudian karena banyaknya tekanan dari masyarakat serta pemerintah daerah untuk lebih mempercepat proses desentralisasi di Indonesia khususnya di daerah tingkat II, maka munculah UU yang baru yaitu UU No 22 Th 1999 tentang pemerintah daerah dan UU No 25 Th 1999 tentang Perimbangan Keuangan Antara Pusat dan Daerah yang menjadi landasan yang kuat dalam pelaksanaan desentralisasi, hingga UU terbaru yaitu UU No 23 Th 2014 tentang Pemerintah Daerah. Oleh karena itu berdasarkan latar belakang di atas maka peneliti tertarik untuk meneliti lebih lanjut tentang Pengaruh Sumber Pembiayaan Desentralisasi fiskal terhadap Produk Domestik Regional Bruto dan Tingkat Kemiskinan.

Berdasarkan latar belakang tersebut, penelitian ini bertujuan untuk menganalisis: 1) sumber pembiayaan desentralisasi fiskal, PDRB dan tingkat kemiskinan kabupatenkota di Provinsi Jambi (2) pengaruh sumber pembiayaan desentralisasi fiskal terhadap produk domestik bruto di kabupaten-kota di Provinsi Jambi (3) pengaruh sumber pembiayaan desentralisasi fiskal terhadap tingkat kemiskinan di kabupaten-kota di Provinsi Jambi.

\section{TINJAUAN PUSTAKA}

Menurut UU No 32 Tahun 2004 tentang Pemerintah Daerah Pasal 1 ayat 7 dan UU No 33 tentang Perimbangan Keuangan Antara Pusat dan Pemerintahan Daerah Pasal 1 ayat 8, "Desentralisasi adalah penyerahan wewenang pemerintahan oleh Pemerintah kepada daerah otonom untuk mengatur dan mengurus urusan pemerintahan dalam system Negara Kesatuan Republik Indonesia.”. Perbedaan konsep desentralisasi ditentukan terutama berdasarkan tingkat kewenangan untuk perencanaan, memutuskan dan mengelola kewenangan yang ditransfer oleh pemerintah pusat dan besaran otonomi yang diterima untuk melaksanakan tugas-tugas tersebut. desentralisasi dapat dibedakan menjadi 4 dimensi, yaitu: (1) Desentralisasi Politik; (2) Desentralisasi Administrasi; (3) Desentralisasi Fiskal; (4) Desentralisasi Ekonomi dan Pasar. Berbagai macam dimensi dan bentuk desentralisasi diatas akan menjadi dasar pembahasan untuk kondisi implementasi di Indonesia, terutama desentralisasi fiskal untuk dapat melihat pengaruhnya terhadap Pertumbuhan Ekonomi (PDRB atas dasar hargaa konstan tahun 2000) dan Tingkat Kemiskinan di kabupaten-kota di Provinsi Jambi.

Menurut Sidik dalam Badrudin (2012), desentralisasi fiskal adalah alat untuk mencapai salah satu tujuan bernegara yaitu terutama memberikan layanan publik yang lebih baik dan menciptakan proses pengambilan keputusan publik yang lebih demokratis dengan melimpahkan kewenangan kepada tingkat pemerintah untuk melakukan pembelanjaan, kewenangan untuk memuungut pajak, terbentuknya dewan yang dipilih oleh rakyat, Kepala Daerah yang dipilih oleh DPRD, dan adanya bantuan dalam bentuk transfer dari pemerintah pusat.Bird dan Vailancourt dalam Kader (2015) menjelaskan kebijakan desentralisasi fiskal dalam konteks desentralisasi dapat meloloskan suatu negara dari berbagai jebakan ketidak efesienan, ketidak efektifan pemerintahan, ketidak stabilan makro ekonomi, dan ketidak cukupan pertumbuhan ekonomi. Desentralisasi fiskal merupakan salah satu bentuk riil dari pengimplemenatasian teori desentralisasi. Melalui desntralisasi fiskal, daerah sebagai daerah otonom dapat memenej potensi dan sumberdaya pendapatan keuangan daerah secara efektif dan efisien.

Menurut Oates dalam Kader (2015) desentralisasi fiskal akan mampu meningkatkan pertumbuhan ekonomi dan kesejahteraan masyarakat pada tingkat lokal, karena pemerintah sub nasional atau pemerintah lokal akan lebih efisien dalam produksi 
dan penyediaan barang-barang publik. Pengambilan keputusan pada tingkat pemerintah lokal akan lebih didengarkan dan pilihan dan penentuan kebutuhan publik yang bersifat lokalistik lebih berguna bagi efisensi dan pengalokasiannya. Lebih lanjut Oates (2008) juga menjelaskan bahwa desentralisasi fiskal dapat meningkatkan efisiensi ekonomi yang kemudian dapat meningkatkan pertumbuhan ekonomi lokal. Sistem belanja infrastruktur dan sektor sosial oleh pemerintah lokal lebih memacu pertumbuhan ekonomi lokal dibandingkan dengan kebijakan yang dilakukan oleh pemerintah pusat. Menurutnya daerah memiliki kelebihan dalam membuat anggaran belanjanya sendiri sehingga belanja akan lebih efisien, sehingga dapat memuaskan kebutuhan masyarakat pada tingkat lokal, karena pemerintah lokal lebih mengetahui keadaannya.

Menurut UU No 33 tahun 2004 Pendapatan Asli Daerah (PAD) adalah pendapatan yang diperoleh daerah yang dipungut berdasarkan peraturan daerah sesuai dengan peraturan perundang-undangan terdiri dari: Pajak Daerah, Retribusi Daerah, Hasil pengelolaan kekayaan daerah yang dipisahkan dan Lain-lain Pendapatan Asli Daerah Yang Sah. Menurut undang - undang No. 33 tahun 2004 menyatakan bahwa dana perimbangan adalah dana yang bersumber dari pendapatan APBN yang dialokasikan kepada daerah untuk membiayai kebutuhan daerah dalam rangka pelaksanaan desentralisasi yang terdiri atas Dana Bagi Hasil (DBH), Dana Alokasi Umum (DAU), dan Dana Alokasi Khusus (DAK). Dana Perimbangan selain dimaksudkan untuk membantu daerah dalam mendanai kewenangannya, juga bertujuan untuk mengurangi ketimpangan sumber pendanaan pemerintahan antara pusat dan daerah serta untuk mengurangi kesenjangan pendanaan pemerintahan antar daerah. Dana perimbangan tersebut merupakan kelompok sumber pembiayaan pelaksanaan desentralisasi yang alokasinya tidak dapat dipisahkan satu sama lain, mengingatkan tujuan masing-masing jenis pendapatan tersebut saling mengisi dan melengkapi. Dan sumber pembiayaan desentralisasi fiskal yang terakhir adalah pendapatan lain-lain yang sah. Pendapatan ini berasal dari sumbangan atau hibah dari pihak ketiga kepada daerah atas dasar kesukarelaan dan persetujuan dari semua pihak.

Pembangunan ekonomi daerah adalah suatu proses dimana pemerintah daerah dan masyarakatnya mengelola sumberdaya-sumberdaya yang ada dan membentuk pola kemintraan antara pemerintah daerah dan sektor swasta untuk menciptakan suatu lapangan kerja baru dan merangsang perkembangan kegiatan ekonomi (pertumbuhan ekonomi) dalam wilayah tersebut (Arsyad, 2010). Masalah pokok dalam pembangunan daerah terletak pada penekanan terhadap kebijakan pembangunan yang didasarkan pada kekhasan daerah yang bersangkutan (endogenous development) dengan menggunakan potensi sumberdaya manusia kelembagaan dan sumberdaya fisik secara lokal (daerah). Faktor penentu utama pertumbuhan ekonomi suatu daerah adalah berkaitan langsung dengan permintaan barang dan jasa dari luar daerah, lokasi dan tingkat pemberian subsidi dan insentif.Salah satu indikator penting untuk mengetahui kondisi ekonomi di suatu wilayah atau provinsi dalam satu periode tertentu ditunjukan oleh data Produk Domestik Regional Bruto (PDRB).

Ada beberapa metode untuk menghitung PDRB, yaitu: (1) Metode langsung yang terdiri dari tiga pendekatan yaitu: Pendekatan Produksi, Pendekatan Pengeluaran dan Pendekatan Pendapatan. (2) Metode Tidak Langsung.Di Indonesia hanya menggunakan Pendekatan Produksi dan Pendekatan Pengeluaran untuk mengukur pertumbuhan ekonomi nasional maupun pertumbuhan ekonomi regional. Ada beberapa faktor yang dapat mempengaruhi pertumbuhan ekonomi regional, yaitu: (1) Tanah dan kekayaan alam lainnya (SDA); (2) Jumlah dan mutu dari penduduk dan angkatan kerja (SDM); (3) Barang-barang modal dan tingkat teknologi; (4) Sistem sosial dan sikap masyarakat (modal sosial); (5) Luas pasar sebagai sumber pertumbuhan (faktor eksternal). 
Teori pertumbuhan ekonomi bisa didefinisikan sebagai penjelasan mengenai faktor-faktor apa saja yang menentukan kenaikan out put perkaita dalam jangka panjang dan penjelasan mengenai bagaimana faktor-faktor tersebut berinteraksi satu sama lain sehingga terjadi proses pertumbuhan (Boediono, 1999). Salah satu teori pertumbuhan ekonomi regional adalah Model Cumulative Causation (Myrdal) pada tahun 1975 dan kemudian diformulasikan lebih lanjut oleh kaldor. Teori ini berpendapat bahwa peningkatan pemerataan pembangunan antar daerah tidak hanya dapat diserahkan pada kekuatan pasar, tetapi perlu adanya campur tangan pemerintah dalam bentuk programprogram pembangunan regional untuk daerah yang masih tertinggal. Daerah maju tetap berkembang secara pesat karena adanya hubungan positif antara kemajuan teknologi dengan tingkat keuntungan perusahaan (usaha). Sedangkan daerah yang kurang berkembang akan tetap berkembang secara lambat karena tingkat keuntungan yang diperoleh usahawan pada daerah ini rendah.

Teori Developmental (bercorak pembangunan) muncul dari teori-teori pembangunan terutama neo-liberal. Teori ini mencari akar masalah kemiskinan pada persoalan ekonomi dan masyarakat sebagai satu kesatuan.Ada tiga asumsi dasar dari teori ini: (1) Negara menjadi miskin karena ketiadaan atribut industrialisasi, modal, kemampuan manajerial, dan prasarana yang diperlukan untuk peningkatan ekonomi; (2) Pertumbuhan ekonomi adalah kriteria utama pembangunan yang dianggap dapat mengatasi masalah-masalah ketimpangan; (3) Kemiskinan akan hilang dengan sendirinya bila pasar diperluas sebesar-besarnya dan pertumbuhan ekonomi dipacu setinggi-tingginya.Ketiga asumsi tersebut memperlihatkan bahwa kemiskinan yang terjadi bukanlah persoalan budaya, sebagaimana anggapan teori marjinal melainkan adalah persoalan ekonomi dan pembangunan.

\section{METODE PENELITIAN}

\section{Jenis dan Sumber Data}

Jenis data yang digunakan adalah data sekunder dalam bentuk data panel. Unit cross section adalah 10 kabupaten-kota di Provinsi Jambi (Kota Sungai Penuh tidak termasuk karena baru berdiri pada tahun 2009) dengan tahun analisis 2007-2013 sebagai unit time series-nya. Data terdiri dari data Pendapatan Asli Daerah (PAD), Dana Perimbangan (DP), Pendapatan Lain-Lain yang Sah (PL), Produk Domestik Regional Bruto (PDRB) atas dasar harga konstan 2000 dan Tingkat Kemiskinan (TK). Sumber data adalah Badan Pusat Statistik (BPS) Provinsi Jambi, yang bersumber Buku Jambi Dalam Angka, Statistik Keuangan Kabupaten-Kota, Data dan Informasi Kemiskinan Kabbupaten-Kota berbagai edisi.

\section{Analisis data}

Model regresi data panel digunakan untuk menganalisis pengaruh sumber pembiayaan desentralisasi fiskal (PAD,DP dan PL) terhadap PDRB dan Tingkat Kemiskinan (TK). Dalam mengestimasi model regresi panel, terdapat 3 pendekatan yang biasa digunakan, yaitu CEM, FEM dan REM (Widarjono,2013).

\section{a. Common Effect Model}

Pendekatan pertama ini merupakan pendekatan paling sederhana yang disebut estimasi CEM atau pooled least square. Pada pendekatan ini diasumsikan bahwa nilai intersep masing-masing variabel adalah sama, begitu pula slope koefisien untuk semua unit cross-section dan time series (Gujarati, 2012). Berdasarkan asumsi ini, maka model CEM dinyatakan sebagai berikut (Widarjono, 2007) :

$$
Y_{i t}=\alpha+\beta_{1} X_{1 i t}+\beta_{2} X_{2 i t}+\beta_{3} X_{3 i t}+\mu_{i t}
$$

Yang kemudian diformulasikan sesuasi dengan permasalahan penelitian ini :

$$
\operatorname{lnPDRB} B_{i t}=\alpha+\beta_{1} \operatorname{lnPAD} D_{i t}+\beta_{2} \operatorname{lnDPit}+\beta_{3} \ln \mathrm{PL}_{\mathrm{it}}+\mu_{\mathrm{it}} \ldots
$$


$\operatorname{lnTK} \mathrm{K}_{\mathrm{it}}=\alpha+\beta_{1} \ln \mathrm{PAD}_{\mathrm{it}}+\beta_{2} \operatorname{lnDP} \mathrm{P}_{\mathrm{it}}+\beta_{3} \operatorname{lnPL} \mathrm{L}_{\mathrm{it}}+\mu_{\mathrm{it}}$

Keterangan Persamaan :

$\mathrm{PE}_{\mathrm{it}} \quad=\mathrm{PDRB}$ atas dasar harga konstan tahun 2000

$\mathrm{TK}_{\mathrm{it}}=$ Tingkat Kemiskinan

$\mathrm{PAD}_{\text {it }}=$ Pendapatan Asli Daerah

$\mathrm{DP}_{\text {it }}=$ Dana Perimbangan

$\mathrm{PL}_{\mathrm{it}} \quad=$ Pendapatan Lain-lain yang Sah

$\alpha \quad=$ Konstanta

$\beta_{1} \quad=$ Nilai koefisien dari Derajat Otonomi Fiskal

$\beta_{2} \quad=$ Nilai koefisien dari Ketimpangan Wilayah

$\beta_{3} \quad=$ Nilai koefisien dari Keterbukaan Daerah

$\mu_{\text {it }} \quad=$ Variabel pengganggu

ln $\quad=$ Logaritma Natural

\section{b. Fixed Effect Model}

Menurut Gujarati (2012), salah satu cara untuk memperhatikan unit cross-section pada model regresi panel adalah dengan mengijinkan nilai intersep berbeda-beda untuk setiap unit cross-section tetapi masih mengasumsikan slope koefisien tetap. Model FEM dapat dinyatakan sebagai berikut (Juanda, 2012):

$$
Y_{\text {it }}=\alpha_{0 i}+\beta_{1} X_{1 i t}+\beta_{2} X_{2 i t}+\beta_{3} X_{3 i t}+\mu_{\text {it }}
$$

Yang kemudian diformulasikan sesuasi dengan permasalahan penelitian ini :

$$
\operatorname{lnPDRB} B_{\text {it }}=\alpha_{0 \mathrm{i}}+\beta_{1} \operatorname{lnPAD} \mathrm{D}_{\mathrm{it}}+\beta_{2} \operatorname{lnDP}_{\mathrm{it}}+\beta_{3} \operatorname{lnPL} \mathrm{L}_{\mathrm{it}}+\mu_{\mathrm{it}}
$$

$\mathrm{i} \quad=1,2,3$, (sebanyak jumlah cross-section)

$\ln \mathrm{TK}_{\mathrm{it}}=\alpha_{0 \mathrm{i}}+\beta_{1} \ln \mathrm{PAD}_{\mathrm{it}}+\beta_{2} \operatorname{lnDP} \mathrm{P}_{\mathrm{it}}+\beta_{3} \operatorname{lnPL_{\mathrm {it}}}+\mu_{\mathrm{it}}$

$\mathrm{t} \quad=1,2,3$, ( sebanyak time series)

Model ini dikenal sebagai model Fixed Effect karena meskipun intersep berbeda untuk setiap unit cross-section, namun intersep ini tidak berbeda atau konstan untuk setiap unit time series (time invariant) (Gujarati, 2012).

\section{c. Random Effect Model}

Pada model REM diasumsikan $\alpha$ i merupakan variabel random dengan mean $\alpha 0$. sehingga intersep dapat dinyatakan sebagai $\alpha i=\alpha 0+\mu \mathrm{i}$ dengan $\mu \mathrm{i}$ merupakan error random yang mempunyai mean 0 dan varians $\sigma \mu 2$, $\mu$ i tidak secara langsung diobservasi atau disebut juga variabel laten. Jadi persamaan model random effect adalah sebagai berikut (Juanda, 2012):

$$
\begin{aligned}
& \text { Yit }=\alpha_{0}+\beta_{1} X_{1 i t}+\beta_{2} X_{2 i t}+\beta_{3} X_{3 i t}+\varepsilon_{i t}+\mu_{i t} \\
& =\alpha_{0}+\beta 1 X_{1 \text { it }}+\beta_{2} X_{2 \text { it }}+\beta_{3} X_{3 i t}+w_{\text {it }} . . .
\end{aligned}
$$

Yang kemudian diformulasikan sesuasi dengan permasalahan penelitian ini :

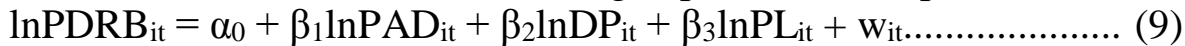

$$
\begin{aligned}
& \operatorname{lnTK} K_{\text {it }}=\alpha_{0}+\beta_{1} \ln P A D_{i t}+\beta_{2} \operatorname{lnDP}_{\text {it }}+\beta_{3} \operatorname{lnPL} L_{i t}+w_{i t}
\end{aligned}
$$

Dengan wit $=\varepsilon i+u i t$. Suku error gabungan wit memuat dua komponen error yaitu $\varepsilon i$ komponen error cross section dan unit yang merupakan kombinasi komponen error cross section dan time series.

\section{Pemilihan Regresi Data Panel}

\section{a. Chow test (Uji Chow)}

Chow test digunakan memilih antara Model Common Effect dan Model Fixed Effect. Asumsi bahwa setiap unit cross section memiliki perilaku yang sama cenderung tidak realistis mengingat dimungkinkannya setiap unit cross section memiliki perilaku yang berbeda menjadi dasar dari uji chow. Dalam pengujian ini dilakukan hipotesis nol $\left(\mathrm{H}_{0}\right)$ yang digunakan adalah insterslop dan slope adalah sama (Juanda, 2012). Adapun uji F statistiknya adalah :

Fhitung $=\frac{R S S_{1}-R S S^{2} / n-1}{\left(R S S^{2}\right) /\left(\frac{n}{T}-n-k\right)}$ 
Dimana :

RSS1 = residual sum of square hasil pendugaan model common effect

$\mathrm{RSS} 2$ = residual sum of square hasil pendugaan model fixed effect

$\mathrm{N}=$ jumlah data cross section

$\mathrm{T}=$ jumlah data time series

$\mathrm{K}=$ jumlah variabel bebas

Statistik Chow Test mengikuti sebaran F-statistik yaitu F(N-1,NT-N-K); $\alpha$. Jika nilai Chow statistik lebih besar dari F-tabel, maka cukup bukti untuk menolak H0 dan sebaliknya.

\section{b. Hausman Test (Uji Hausman)}

Uji hausman digunakan untuk membandingkan model Fixed Effect dengan Random effect. Alasan dilakukannya uji hausman didasarkan pada model fixed effect model yang mengandung suatu unsur trade off yaitu hilangnya unsur derajat bebas dengan memasukkan variabel dummy dan model Random Effect yang harus memperhatikan ketiadaan pelanggaran asumsi dari setiap komponen galat. Dalam pengujian ini dilakukan hipotesis sebagai berikut :

$\mathrm{W}=\mathrm{X}^{2}[\mathrm{~K}]=\left[\beta^{\wedge}, \beta_{\mathrm{GLS}}\right] \sum-1\left[\beta^{\wedge}-\beta_{\mathrm{GLS}}\right]$

Uji hausman mengikuti distribusi statistik chi-squre dengan derajat bebas sebanyak jumlah peubah bebas. Hipotesis nol ditolak jika nilai statistik Hausman lebih besar daripada nilai kritis statistik chi-squre. Ini berarti bahwa model yang tepat untuk regresi data panel adalah model Fixed Effect (Juanda dan Junaidi, 2012).

\section{c. Lagrange Multiplier Test (Uji LM)}

Pengujian ini berdasarkan pada nilai residual dari model Common Effect. Hipotesis nol $\left(\mathrm{H}_{0}\right)$ yang digunakan adalah intersep bukan peubah random atau stokastik (Juanda dan Junaidi, 2012). Dengan formulasi sebagai berikut :

$L M=\frac{n T}{2(T-1)}\left[\frac{\sum_{i=1}^{n}\left[\sum_{i=1}^{t} e i t\right] 2}{\sum_{i=1}^{n} \sum_{i=1}^{T} \text { eit } 2}\right]$

Statistik uji LM adalah sebagai berikut (Juanda dan Junaidi, 2012):

dengan:

$\mathrm{T}=$ jumlah unit time series

$\mathrm{n}=$ jumlah unit cross section

$\sigma \mathrm{i} 2=$ variansi residual persamaan $\mathrm{ke}-\mathrm{i}$

$\sigma 2=$ variansi residual persamaan sistem

Uji LM disarankan pada distribusi chi-squre dengan derajat bebas sebesar 1. Jika hasil statistik LM lebih besar dari nilai krisis statistik chi-squre, maka hipotesis nol akan ditolak, yang berarti estimasi yang tepat untuk regresi data panel adalah metode Random Effect.

\section{Operasional Variabel}

\section{Produk Domestik Regional Bruto}

Produk Domestik Regional Bruto selanjutnya disingkat menjadi PDRB yang dipakai dalam penelitian ini adalah PDRB atas dasar harga konstan tahun 2000 di kabupaten-kota Provinsi Jambi dari tahun 2007-2013 dinyatakan dalam jutaan rupiah.

\section{Tingkat Kemiskinan}

Variabel Tingkat Kemiskinan selanjutnya disingkat menjadi TK yang dipakai dalam penelitian ini adalah persentase jumlah penduduk miskin di kabupaten-kota Provinsi jambi dari Tahun 2007-2013. Dalam penelitian ini tingkat kemiskinan dinyatakan dalam persentase.

\section{Sumber Pembiayaan Desentralisasi Fiskal terdiri dari: \\ a. Pendapatan Asli Daerah}


Pendapatan Asli Daerah selanjutnya disingkat menjadi PAD yang dipakai dalam penelitian ini adalah PAD di kabupaten-kota Provinsi Jambi dari tahun 2007-2013. Dalam penelitian ini PAD dinyatakan dalam bentuk ribu rupiah.

b. Dana Perimbangan

Dana perimbangan selanjutnya disingkat menjadi DP yang dipakai dalam penelitian ini adalah DP di kabupaten-kota Provinsi Jambi dari tahun 2007-2013. Dalam penelitian ini dana perimbangan dinyatakan dalam bentuk ribu rupiah.

c. Pendapatan Lain-Lain yang Sah

Pendapatan Lain-Lain yang Sah selanjutnya disingkat menjadi PL yang dipakai dalam penelitian ini adalah PL di kabupaten-kota Provinsi Jambi dari tahun 2007-2013. Dalam penelitian ini pendapatan lain-lain yang sah dinyatakan dalam bentuk ribu rupiah.

\section{HASIL DAN PEMBAHASAN}

\section{PAD, dana perimbangan, PDRB dan tingkat kemiskinan kabupaten/kota di Provinsi Jambi}

Secara umum rata-rata PAD Kabupaten-kota di Provinsi Jambi tiap tahun cenderung mengalami tren yang terus meningkat liat Tabel. Hal ini menggambarkan bahwa kemampuan daerah dalam menggali potensi dan sumber-sumber penerimaan daerah selama ini dinilai cukup berhasil. Pada tahun 2007 nilai rata-rata PAD sebesar Rp. 20,38 miliar, pada tahun 2013 mencapai Rp. 58,16 miliar.perkembangan pertumbuhan PAD, rata-rata perkembangan PAD di Kabupaten-kota di Provinsi Jambi adalah sebesar 22,32\% dari tahun 2007 - 2013. Daerah yang memiliki rata-rata perkembangan PAD tertinggi adalah Kabupaten Kerinci dengan perkembangan sebesar $32,29 \%$ dan daerah yang memiliki rata-rata perkembangan terendah adalah Kabupaten Bungo yaitu sebesar 11,22\%. Hingga Pada tahun 2013 semua Kabupaten-kota kembali mengalami peningkatan dengan rata-rata perkembangan sebesar 32,01\%. Daerah yang memiliki perkembanngan terbesar adalah Kabupaten Kerinci dengan 79,91\%, diikuti Kabupaten Merang 47,43\%. Daerah yang perkembangan PAD-nya terendah adalah Kabupaten Tanjung Jabung Timur sebesar 5,22\%. Walaupun perkembangan PAD Kabupaten Tanjung Jabung Timur pada tahun 2013 merupakan yang terkecil, akan tetapi Kabupaten Tanjung Jabung Timur adalah kabupaten yang PAD-nya tidak pernah mengalami penurunan dari tahun sebelumnya (bersama dengan Kota Jambi).

Dana perimbangan merupakan pendapatan daerah yang berasal dari pemerintah pusat yang merupakan cerminan atau indikator dari ketergantungan pendapatan pemerintah daerah terhadap pemerintah pusat. Disamping itu besarnya dana perimbangan tersebut berbeda-beda pada setiap daerah tergantung dari potensi yang dimiliki oleh daerah tersebut. Rata-rata penerimaan daerah dari dana perimbangan semua Kabupaten-kota di Provinsi Jambi pada kisaran Rp. 3,8 triliun dari tahun 20072009. Dana Perimbangan tertinggi disumbangkan oleh Kabupaten Tanjung Jabung Barat dengan jumlah dana perimbangan sebesar Rp. 4,8 Triliun. Sedangkan daerah yang memiliki dana perimbangan terendah adalah Kabupaten Tebo sebesar Rp. 3,2 triliun. Dari tahun 2009 - 2013 Kabupaten Tanjung Jabung Timur selalu menjadi daerah yang memperoleh dana perimbangan terbesar dibandingkan kabupaten atau kota yang ada di Provinsi Jambi.

Salah satu sumber pembiayaan pelaksanaan desentralisasi fiskal adalah pendapatan lain-lain yang sah. Pendapatan ini berasal dari sumbangan atau hibah dari pihak ketiga kepada daerah atas dasar kesukarelaan dan persetujuan dari semua pihak.Rata-rata perkembangan pendapatan lain-lain yang sah selalu meningkat dari tahun 2007-2011. Pada tahun 2012 terjadi penurunan namun pada tahun 2013 rata-rata pendapatan lain-lain yang sah kembali mengalami kenaikan. Kota Jambi menjadi daerah 
yang paling sering menerima pendapatan lain-lain yang sah tertinggi yaitu pada tahun 2011, 2012, 2013, sedangkan Kabupaten Bungo dan Tanjung Jabung Timur sama-sama menjadi daerah yang mendapatkan penerimaan tertinggi 2 tahun. Kabupaten Bungo pada tahun 2007 dan 2010, sedangkan Kabupaten Tanjung Jabung Timur pada tahun 2008-2009.

PDRB di Kabupaten-kota di Provinsi Jambi setiap tahun mengalami peningkatan. Kota Jambi menjadi daerah dengan penyumbang PDRB terbesar dari tahun 2007-2013 dan Kabupaten Tebo menjadi daerah dengan penyumbang PDRB terendah. Pada tahun 2007 rata-rata PDRB Kabupaten-kota Provinsi Jambi sebesar Rp. 1,3 miliar meningkat pada tahun 2008 menjadi Rp. 1,4 miliar, tahun 2009 meningkat menjadi Rp. 1,5 miliar hingga pada tahun 2013 rata-rata PDRB kabupaten-kota Provinsi Jambi mnejadi Rp. 1,99 miliar. Dari uraian di atas jika kita perhatikan keadaan pertumbuhan PDRB yang mencerminkan pertumbuhan ekonomi daerah setiap tahun mengalami tingkat pertumbuhan yang berbeda pada setiap kabupaten-kota di Provinsi Jambi. Hal tersebut dipengaruhi oleh beberapa faktor seperti sumberdaya alam, sumberdaya manusia, modal dan teknologi. Dapat disimpulkan bahwa Kabupatrn Sarolangiun menjadi kabupaten di Provinsi Jambi yang sering memiliki pertumbuhan PDRB tertinggi, sedangkan Kabupaten Tanjung Jabung Timur sering memiliki pertumbuhan ekonomi terendah di Provinsi Jambi.

Tingkat kemiskinan (persentase jumlah penduduk miskin), pada tahun 2007 ratarata tingkat kemiskinan di kabupaten-kota di Provinsi Jambi adalah 10,965\%. Daerah yang tingkat kemiskinan paling tinggi adalah Kabupaten Sarolangun yaitu sebesar 16,11 sedangkan daerah dengan tingkat kemiskinan terendah adalah Kota Jambi yaitu sebesar 5,04\%. Pada tahun 2008 rata-rata tingkat kemiskinan di kabupaten-kota di Provinsi Jambi menurun menjadi $9,375 \%$. Daerah yang tingkat kemiskinan paling tinggi adalah Kabupaten Tanjung Jabung Timur dan Tanjung Jabung Barat yaitu sebesar 13,49\% dan $13,43 \%$. Sedangkan daerah dengan tingkat kemiskinan terendah adalah Kabupaten Muaro Jambi yaitu sebesar 4,35\%.

Pada tahun 2009 rata-rata tingkat kemiskinan di kabupaten-kota di Provinsi Jambi mengalami penurunan menjadi 8,62\% lalu meningkat ditahun 2010 menjadi 8,65\%, turun kembali ke angka 8,14\% dan meningkat kembali pada tahun 2012 dan 2013 menjadi 8,559\% dan 8,604\%. Dari rentan waktu 2009-2013 Kabupaten Tanjung Jabung Timur selalu menjadi daerah dengan tingkat kemiskinan tertinggi dengan rata-rata sebesar $12,72 \%$. Sedangkan untuk daerah dengan tingkat kemiskinan terendah adalah Kabupaten Muaro Jambi dengan rata-rata sebesar 5,14\%.

\section{Pengaruh sumber pembiayaan desentralisasi fiskal terhadap PDRB}

Berdasarkan uji Chow, uji Haussman dan uji Lagrange Multiplier, model regresi data panel terbaik untuk menganalisis pengaruh sumber pembiayaan desentralisasi fiskal terhadap PDRB adalah melalui pendekatan Fixed Effect . Hasil estimasi model diberikan sebagai berikut:

$$
\begin{aligned}
& \mathrm{PDRB}_{\mathrm{it}}=5,16+0,07 \mathrm{PAD}_{\mathrm{it}}+0,36 \mathrm{DP}_{\mathrm{it}}+0,04 \mathrm{PL}_{\mathrm{it}} \\
& \begin{array}{lllll}
\mathrm{SE} & =0.44 & 0.02 & 0.03 & 0.007
\end{array} \\
& \begin{array}{llll}
\mathrm{t} \text {-stat } & =11,75 \quad 3,45 & 10.63 & 5.85
\end{array} \\
& \mathrm{R}^{2} \quad=0.99 \\
& \mathrm{~F} \quad=1109
\end{aligned}
$$


Tabel 1. Nilai Intersep Fixed Effect Kabupaten-kota Provinsi Jambi

\begin{tabular}{|c|c|c|}
\hline No & Kabupaten-kota & Nilai Intersep \\
\hline 1 & Batanghari & -0.190636 \\
\hline 2 & Bungo & -0.181333 \\
\hline 3 & Kerinci & -0.249938 \\
\hline 4 & Merangin & -0.222838 \\
\hline 5 & Muaro Jambi & -0.189725 \\
\hline 6 & Sarolangun & -0.129222 \\
\hline 7 & Tanjung Jabung Barat & 0.358395 \\
\hline 8 & Tanjung Jabung Timur & 0.490631 \\
\hline 9 & Tebo & -0.407633 \\
\hline 10 & Kota Jambi & 0.722299 \\
\hline
\end{tabular}

\section{Uji Hipotesis}

Nilai $F_{\text {hitung }}$ adalah 1109,254 dan $F_{\text {tabel }} 2$ 2,74. dengan tingkat signifikansi 5\%. Dari perbandingan nilai $F_{h i t u n g}>F_{\text {tabel}}$, ditarik kesimpulan $\mathrm{H}_{0}$ ditolak yang berarti sumber pembiayaan desentralisasi fiskal (PAD, DP dan PL) secara bersama-sama berpengaruh signifikan terhadap produk domestik regional bruto di Kabupaten-kota di Provinsi Jambi. Nilai R2 sebesar 0,9957, menunjukkan bahwa pertumbuhan ekonomi dipengaruhi oleh sumber pembiayaan desentralisasi fiskal (PAD, DP dan PL) sebesar 99\%; sedangkan sisanya sebesar $1 \%$ dipengaruhi oleh faktor lain yang tidak termasuk dalam penelitian ini.

Nilai t-hitung koefisien PAD $=3,45$ dan nilai t-tabel $=1,67$ dengan signifikansi $\alpha=5 \%$. Karena nilai t-hitung > t-tabel maka $\mathrm{H}_{0}$ ditolak, dan $\mathrm{H}_{1}$ diterima. Ditarik kesimpulan PAD berpengaruh positif dan signifikan terhadap PDRB Kabupaten-kota di Provinsi Jambi.

Nilai t-hitung dana perimbangan $(\mathrm{DP})=10,63$ dan nilai t-tabel 1,67 dengan signifikansi $\alpha=5 \%$. Karena nilai t-hitung > t-tabel maka $\mathrm{H}_{0}$ ditolak, dan $\mathrm{H}_{1}$ diterima. Ditarik kesimpulan DP berpengaruh positif dan signifikan terhadap PDRB Kabupatenkota di Provinsi Jambi.

Nilai t-hitung pendapatan lain-lain yang sah $(\mathrm{PL})=5,85$ dan nilai t-tabel 1,67 dengan signifikansi $\alpha=5 \%$. Karena nilai t-hitung > t-tabel maka $\mathrm{H}_{0}$ ditolak, dan $\mathrm{H}_{1}$ diterima. Ditarik kesimpulan PL berpengaruh positif dan signifikan terhadap PDRB Kabupaten-kota di Provinsi Jambi.

\section{Pembahasan dan Interpretasi Hasil}

Berdasarkan hasil persamaan regresi, terlihat koefisien regresi dari variabel PAD sebesar 0,06. Artinya jika PAD kabupaten-kota di Provinsi Jambi selama tahun 20072013 naik sebesar 1\% maka PDRB kabupaten-kota di Provinsi Jambi akan meningkat sebesar $0,06 \%$ dengan asumsi cateris paribus (variabel lain dianggap tetap). Untuk DP dengan koefisien sebesar 0,35 artinya jika DP kabupaten-kota di Provinsi Jambi selama tahun 2007-2013 naik sebesar 1\% maka PDRB kabupaten-kota di Provinsi Jambi juga akan naik sebesar $0,35 \%$ dengan asumsi cateris paribus (variabel lain dianggap tetap). Sedangkan untuk PL dengan koefisien sebesar 0,04 artinya jika PL kabupaten-kota di Provinsi Jambi selama tahun 2007-2013 naik sebesar 1\% maka PDRB kabupaten-kota di Provinsi Jambi akan naik sebesar 0,04\% dengan asumsi cateris paribus (variabel lain dianggap tetap). 
Model Fixed Effect memiliki intersep yang berbeda tiap kabupaten/kota (Tabel 1) Keadaan tersebut dapat dijelaskan bahwa PAD, DP dan PL memiliki tingkat pengaruh yang berbeda terhadap pertumbuhan ekonomi pada tiap-tiap kabupaten-kota di Provinsi Jambi maupun tiap tahunnya. Sebagai contoh Kabupaten Batanghari yang memiliki nilai intersep 4,973 didapat dari $(-0,1906+5,1636)$ artinya jika terjadi perubahan PAD, DP dan PL baik antar daerah maupun antar waktu, maka Kabupaten Batanghari akan mendapatkan pengaruh individu terhadap PDRB sebesar 4,973\%. Dan seterusnya untuk Kabupaten-Kota lainnya, nilai interseb dapat dilihat di tabel 1.1.

Hasil dalam penelitian ini sesuai dengan hubungan PAD, DP dan PL terhadap PDRB yang menjelaskan bahwa adanya kenaikan PAD, DP, dan PL akan memicu dan memacu PDRB daerah menjadi lebih baik dari pada PDRB daerah sebelumnya. Hal ini juga sesuai dengan penelitian yang dilakukan Rini (2014), Anisa (2015) dan M. Rizky (2011) bahwa PAD, Dana Perimbangan yang terdiri dari (DAU, DAK, dan DBH) mempunyai hubugan yang positif dan signifikan terhadap Produk Domestik Regional Bruto.

\section{Pengaruh sumber pembiayaan desentralisasi fiskal terhadap tingkat kemiskinan}

Berdasarkan uji Chow, uji Haussman dan uji Lagrange Multiplier, model regresi data panel terbaik untuk menganalisis pengaruh sumber pembiayaan desentralisasi fiskal terhadap PDRB adalah melalui pendekatan Random Effect. Hasil estimasi model diberikan sebagai berikut:

$\begin{array}{lllll}\mathrm{TK}_{\mathrm{it}} & =6,03 & -1,44 \mathrm{PAD}_{\mathrm{it}}+1,97 \mathrm{DP}_{\mathrm{it}}-0,67 \mathrm{PL}_{\mathrm{it}} \\ \mathrm{SE} & =18,57 & 0,77 & 1,37 & 0,31 \\ \mathrm{t}-\text { stat } & =0,32 & -1,87 & 1,44 & -2,16 \\ \mathrm{R}^{2} & =0.22 & & & \\ \mathrm{~F} & =6,33 & & & \end{array}$

Tabel 2. Nilai Intersep Random Effect Kabupaten-kota Provinsi Jambi

\begin{tabular}{|c|c|c|}
\hline No & Kabupaten-kota & Nilai Intersep \\
\hline 1 & Batanghari & 1.5168 \\
\hline 2 & Bungo & -1.7884 \\
\hline 3 & Kerinci & -0.9696 \\
\hline 4 & Merangin & -0.3788 \\
\hline 5 & Muaro Jambi & -4.1671 \\
\hline 6 & Sarolangun & 1.49723 \\
\hline 7 & Tanjung Jabung Barat & 2.0109 \\
\hline 8 & Tanjung Jabung Timur & 2.97323 \\
\hline 9 & Tebo & -2.3558 \\
\hline 10 & Kota Jambi & 1.66157 \\
\hline
\end{tabular}

\section{Uji Hipotesis}

Nilai $F_{\text {hitung }}$ adalah 6,34 dan $\mathrm{F}_{\text {tabel }}$ 2,74 dengan tingkat signifikansi 5\%. Dari perbandingan nilai $\mathrm{F}_{\text {hitung }}>\mathrm{F}_{\text {tabel }}$, ditarik kesimpulan $\mathrm{H}_{0}$ ditolak yang berarti sumber pembiayaan desentralisasi fiskal (PAD, DP dan PL) secara bersama-sama berpengaruh signifikan terhadap tingkat kemiskinan di Kabupaten-kota di Provinsi Jambi. 
Nilai R2 sebesar 0,22. Hal ini menunjukkan bahwa tingkat kemiskinan dipengaruhi oleh sumber pembiayaan desentralisasi fiskal (PAD, DP dan PL) sebesar $22 \%$; sedangkan sisanya sebesar $78 \%$ dipengaruhi oleh faktor lain yang tidak termasuk dalam penelitian ini.

Nilai t-hitung PAD sebesar -1.87 dan nilai t-tabel 1,67 dengan signifikansi $\alpha=5 \%$. Karena nilai t-hitung > t-tabel maka $\mathrm{H} 0$ ditolak, dan $\mathrm{H} 1$ diterima. Ditarik kesimpulan PAD berpengaruh negatif dan signifikan terhadap tingkat kemiskinan Kabupaten-kota di Provinsi Jambi.

Nilai t-hitung dana perimbangan $(\mathrm{DP})=1,44$ dan nilai t-tabel 1,67 dengan signifikansi $\alpha=5 \%$. Karena nilai t-hitung < t-tabel maka H0 diterima, dan H1 ditolak. Ditarik kesimpulan DP tidak berpengaruh signifikan terhadap tingkat kemiskinan Kabupaten-kota di Provinsi Jambi.

Nilai t-hitung pendapatan lain-lain yang sah $=-2,16$ dan nilai t-tabel 1,67 dengan signifikansi $\alpha=5 \%$. Karena nilai t-hitung > t-tabel (maka H0 ditolak, dan H1 diterima. Ditarik kesimpulan PL berpengaruh negatif dan signifikan terhadap tingkat kemiskinan Kabupaten-kota di Provinsi Jambi.

\section{Pembahasan dan Interpretasi Hasil}

Koefisien regresi dari variabel PAD sebesar -1,44, artinya jika PAD kabupatenkota di Provinsi Jambi naik sebesar 1\% maka tingkat kemiskinan kabupaten-kota di Provinsi Jambi akan turun sebesar 1,44\% dengan asumsi cateris paribus (variabel lain dianggap tetap). Dana perimbangan tidak berpengaruh terhadap kemiskinan, sedangkan untuk PL dengan koefisien sebesar -0,67 menunjukkan jika PL kabupaten-kota di Provinsi Jambi selama tahun 2007-2013 naik sebesar 1\% maka tingkat kemiskinan kabupaten-kota di Provinsi Jambi akan turun sebesar 0,67\% dengan asumsi cateris paribus (variabel lain dianggap tetap).

Model Random Effect memiliki intersep yang berbeda tiap kabupaten/kota (Tabel 2). Keadaan tersebut dapat dijelaskan bahwa PAD, DP dan PL memiliki tingkat pengaruh yang berbeda terhadap tingkat kemiskinan pada tiap-tiap kabupaten-kota di Provinsi Jambi maupun tiap tahunnya. Sebagai contohnya Kabupaten Batanghari yang memiliki nilai intersep 7,5476 didapat dari $(1,5168+6,0308)$ artinya jika terjadi perubahan PAD, DP dan PL baik antar daerah maupun antar waktu, maka Kabupaten Batanghari akan mendapatkan pengaruh individu terhadap tingkat kemiskinan sebesar $7,55 \%$.

\section{KESIMPULAN DAN SARAN}

\section{Kesimpulan}

1. Selama periode 2007-2013, sumber pembiayaan desentralisasi fiskal yang terdiri Pendapatan Asli Daerah, Dana Perimbangan dan Pendapatan Lain-lain yang Sah di kabupaten-kota di Provinsi Jambi umumnya selalu mengalami kenaikan setiap tahunnya.

2. Pertumbuhan PDRB kabupaten-kota di Provinsi Jambi terbilang cukup tinggi dengan rata-rata $6,83 \%$, lebih tinggi dari pertumbuhan ekonomi nasional.

3. Secara umum, tingkat kemiskinan kabupaten-kota di Provinsi Jambi selalu mengalami penurunan yang signifikan setiap tahunnya selama periode 2007 2013.

4. PAD, dana perimbangan dan dan pendapatan lain yang sah mempunyai pengaruh positif dan signifikan terhadap peningkatan produk domestik regional bruto kabupaten-kota di Provinsi Jambi. 
5. PAD dan pendapatan lain yang sah mempunyai pengaruh yang negatif dan signifikan sedangkan dana perimbangan tidak memiliki pengaruh yang signifikan terhadap tingkat kemiskinan kabupaten-kota di Provinsi Jambi.

\section{Saran}

Penyelenggara masing-masing pemerintah kabupaten-kota di Provinsi Jambi harus mengoptimalkan PAD agar dapat menambah penerimaan daerah di daerah masing-masing. Selain bertujuan peningkatan pertumbuhan produk domestik regional bruto yang tinggi penyelenggara masing-masing pemerintah tingkat kabupaten-kota di Provinsi Jambi juga harus memperhatikan dan mengendalikan jumlah penduduk miskin. Selanjutnya pemerintah tingkat kabupaten-kota di Provinsi Jambi harus mengoptimalkan sumber penerimaan daerah yang lain yaitu pendapatan lain-lain yang sah dan dana yang bersumber dari pemerintah pusat untuk menyediakan layanan publik dan fasilitas umum yang diperlukan guna memperlancar perekonomian di daerah sehingga roda perekonomian terus bergerak serta dapat merangsang dan mempercepat pertumbuhan produk domestik regional bruto dan pengurangan jumlah penduduk miskin yang tinggi.

\section{DAFTAR PUSTAKA}

Amir,Amri, 2007.Perekonomian Indonesia (Dalam Perspektif Makro).Penerbit Biografika.Bogor.

Arsyad, Lincolin. 2010. Ekonomi Pembangunan. STIE YKPN.Yogyakarta.

Badrudin, Rudy. 2012.Ekonomika Otonomi Daerah. UPP STIM SKPN.Yogyakarta.

Boediono. 1999.Seri Sinopsis Pengantar Ilmu Ekonomi No. 4: Teori Pertumbuhan Ekonomi, BPFE.Yogyakarta.

Deliarnov. 2012. Perkembangan Pemikiran Ekonomi. Rajawali Pers. Jakarta.

Devita, A., Delis, A., \& Junaidi, J. (2014). Pengaruh Pendapatan Asli Daerah, Dana Alokasi Umum dan Jumlah Penduduk terhadap Belanja Daerah Kabupaten/Kota di Provinsi Jambi. Jurnal Perspektif Pembiayaan dan Pembangunan Daerah, 2(2), 63-70.

Gujarati, Damodar N. 2012. Ekonometrika Dasar.Erlangga.Jakarta.

Nopriansyah, N., Junaidi, J., \& Umiyati, E. (2015). Determinan Kemiskinan Rumah Tangga di Provinsi Jambi. Jurnal Perspektif Pembiayaan dan Pembangunan Daerah, 2(3), 119-128.

Parmadi, slamet rahmadi. 2010.keuangan daerah. Universitas Jambi, Jambi.

Parmadi. 2010.Modul Ekonomi Publik, Universitas Jambi, Jambi.

Soekirno,Sadono. 2011. Pengantar Teori Makro Ekonomi Edisi Ketiga. PT.Raja Grafindo Persada. Jakarta.

Widaryono, Agus. 2013. EKONOMETRIKA Pengantar dan Aplikasinya. UPP STIM SKPN.Yogyakarta.

Winarno, Wing Wahyu. 2011. Analisis Ekonometrika dan Statistik dengan Eviews Edisi ke 3. UPP STIM YKPN.Yogyakarta. 